\title{
PERAN KEPALA DESA SEBAGAI OPINION LEADER DI DESA BUKIT HARAPAN
}

\author{
Wijoko Lestariono \\ Fakultas IImu Sosial dan IImu Politik Universitas Palangka Raya \\ (email: wijikolestariono@gmail.com) \\ Hendro \\ Fakultas IImu Sosial dan IImu Politik Universitas PGRI Palangka Raya
}

\begin{abstract}
Abstrak
Penelitian ini bertujuan untuk (1) Untuk mendeskripsikan peranan Kepala Desa dalam membangun citra kerja yang baik terhadap warga pada masyarakat di Desa Harapan Kabupaten Kotawaringin Timur. (2) Untuk mendeskripsikan peranan Kepala Desa dalam meningkatkat hubungan komunikasi kepada masyarakat di Desa Bukit Harapan Kabupaten Kotawaringin Timur.

Jenis penelitian ini adalah metode deskriptif kualitatif metode yang hanya memaparkan, menuliskan, dan melaporkan keadaan suatu objek ataupun suatu peristiwa yang berupa penyingkapan sebuah fakta. Sedangkan metode studi kasus adalah metode penelitian tentang subjek penelitian berupa individu, kelompok, lembaga, atau masyarakat, yang berkenaan dengan suatu fase atau tahap, sehingga dapat memberikan gambaran secara mendetail tentang latar belakang, sifat dan karakter yang khas dari suatu kasus.

Hasil penelitian ini dapat disimpulkan : 1) Dalam peraturan desa Kepala Desa di Desa Bukit Harapan Kecamatan Parenggean Kabupaten Kotawaringin Timur telah menyelesaikan proker desa yang dibuat dan semua anggota ikut serta dalam menjalankan proker kerja, dan visi/misi yang ada didesa sangat berjalan dengan baik, serta sekertaris desa sangat membantu dalam peraturan desa yang dijalankan dalam pemerintahan. 2) Hambatan yang dialami di kantor pemerintahan desa masih sangat kurangnya keterlibatan masyarakat terhadap program yang telah disusun oleh pemerintah desa, untuk selanjutnya agar partisifasi warga bisa ditingkatkan lagi agar proses pembangunan desa dapat berjalan dengan lancar adanya komunikasi yang baik antara pemerintah desa dan warganya.
\end{abstract}

\section{Kata kunci : Peran Kepala Desa, Opinion Leader}

\section{Pendahuluan}

Dominannya peran kepala desa atau pemimpin dalam sistem sosial pada masyarakat Indonesia membuat posisi para kepala desa sangat penting. Sehingga masyarakat sering menjadikan kepala desa atau pemimpin sebagai rujukan dalam masalah kehidupan sehari-hari, seperti

\section{Jurnal Sociopolitico}


urusan politik, urusan warga, bahkan urusan-urusan rumah tangga.

Kesiapan masyarakat dalam menerima seorang pemimpin memanglah menjadi hal yang harus diperhatikan. Berbagai macam para calon-calon pemimpin untuk menarik perhatian masyarakat agar memilihnya menjadi seorang pemimpin. Dari memberikan janji, sampai dengan membuktikannya hanya di awal saja. Maka dalam pemilihan tersebut peran opinion leader sangat diperlukan. Karena opinion leader mempunyai keunggulan dari masyarakat.

Fenomena setiap pemilihan memanglah sangat sulit dilakukan terutama dengan masyarakat, karena dalam pemilihan pemimpin harus tepat dan dapat dipercaya menjalankan amanah yang diberikan, sebab jika mencari pemimpin yang hanya mementingkan dirinya sendiri maka harus diperimbangkan kembali supaya seorang pemimpin menjadi panutan oleh warganya.

Peranan kepala desa selaku pimpinan dalam melaksanakan upaya peningkatan mutu kelanjutan kantor desa cenderung lebih banyak mementingkan pekerjaannya sendiri dibanding mengutamakan warganya, maka dari itu kepala desa harus merubah pola komunikasinya terhadap warganya sehingga tidak terjadi kesalahpahaman sesama.

Peran kepala desa cenderung masih kurang baik terhadap masyarakat dalam meningkatkan hubungan komunikasi, kepala desa harus bisa lebih memperhatikan lagi masyarakat agar hubungan komunikasinya lebih baik lagi.

Opinion Leader mempunyai peranan yang sangat besar dalam meneruskan informasi walaupun dengan kemungkinan adanya seleksi atau pengalihan informasi, maupun dalam menafsirkan informasi yang mereka terima. Sebab informasi yang disampaikan oleh para calon-calon pemimpin sangat bergantung pada cara mereka menafsirkan informasi yang mereka dapatkan, kemudian akan berkembang menjadi pengaruh pribadi. Pergeseran peranan sebagai sumber informasi oleh media massa televisi di wilayah pedesaan. Masyarakat juga mempunyai kapasitas mempengaruhi secara informal atas warganya.

Salah satu unsur yang sangat mempengaruhi kurangnya komunikasi, khususnya di pedesaan. Berbagai perubahan dan kemajuan masyarakat sangat ditentukan oleh opinion leader. Misalnya, pemimpin opini bisa berperan memotivasi masyarakat agar ikut serta secara aktif dalam pembangunan. Untuk itulah pemerintah memberikan perhatian khusus kepada opinion leader ini. Sikap meremehkan peran justru merugikan sebab program pembangunan akan banyak hambatan, misalnya tentang kepercayaan masyarakat pada program pembangunan. Selayaknya pemerintah memfungsikan Kepala Desa sebagai tokoh sentral dalam pembangunan diwilayah pedesaan.

Masyarakat di Desa Bukit Harapan Kecamatan Parenggean Kabupaten Kotawaringin Timur adalah masyarakat yang majemuk terdapat bermacam-macam agama, dan suku dalam kehidupan seharihari masyarakat Desa Bukit Harapan Kecamatan Parenggean Kabupaten Kotawaringin Timur menjadikan kepala desa sebagai rujukan dalam setiap permasalahan yang ada dalam kehidupan sehari-hari bahkan sampai dalam ranah atau wilayah sosial politik.

Kepala desa pada dasarnya merupakan komunikator politik yang

\section{Jurnal Sociopolitico}


memiliki peran signifikan, watak ketaatan masyarakat pada kepala desa yang dianggapnya sebagai pimpinan dan sumber informasi, cukup memberikan pengaruh signifikan pada tingkah laku politik yang diperankannya, dikalangan masyarakat kepala desa menjadi kata kunci, sekaligus kata akhir dalam menentukan banyak hal, termasuk dalam menentukan sikap dan perilaku politiknya.

Sementara realita yang ada di masyarakat Desa Bukit Harapan, bahwa setiap ada pemilihan kepala desa mereka selalu meminta saran kepada Tokoh adat atau pemimpin senior dalam menentukan siapa yang akan mereka pilih.

Dan kepala desa pada penelitian ini menggunakan otoritasnya sebagai alat untuk menghimpun dukungan untuk menjadikan salah satu kepala desa yang di inginkan terpilih dengan menggunakan cara-cara yang kurang baik (untuk ukuran dia sebagai orang yang mengerti hukum agama). Seperti menggunakan kampanye hitam, atau sebuah kampanye yang bertujuan untuk menjatuhkan figur calon kandidat yang akan mengikuti proses pemilihan kepala desa. Indikasi semacam ini cukup terlihat dengan adanya perpecahan kelompok masyarakat ketika akan menghadapi pemilihan kepala desa.

Dalam hal ini tiap kelompok mempunyai rujukan masing-masing, yang biasanya berupa seorang kepala desa atau figur pemimpin spiritual di desa tersebut, tentu yang menjadi pemicu atau penyebab bukan hanya kepala desa itu saja, melainkan juga beberapa elit pemimpin atau publik figur di desa itu. Seperti mantan kepala desa atau figur yang disegani dan cenderung mempunyai pengaruh di masyarakat desa itu.

Sementara itu kepala desa sebagai opinion leader dalam hal ini bukan hanya panutan dalam pendapat-pendapatnya, melainkan juga ada yang mengasumsikan bahwa fatwa kepala desa merupakan kepanjangan dari suara pemerintah untuk dianut oleh masyarakat tersebut, masalahnya antara pemimpin satu (dalam hal ini kepaala desa di Desa Bukit Harapan Kecamatan Parenggean Kabupaten Kotawaringin Timur) ada pandangan yang berbeda-beda, tentu saja bagi pengikut atau masyarakat akan terjadi gap atau kesenjangan antara kelompok kepala desa satu dan yang lainnya, mulai dari perdebatan ringan sampai adu mulut yang menjurus pada perilaku kasar untuk melakukan suatu intimidasi terhadap kelompok lain.

Opinion leader adalah orang yang mempunyai keunggulan dari pada masyarakat kebanyakan. Salah satu keunggulan opinion leader dibandingkan dengan masyarakat kebanyakan adalah pada umumnya opinion leader itu lebih mudah menyesuaikan diri dengan masyarakatnya, lebih kompeten dan lebih mengetahui tata cara memelihara norma yang ada di dalam masyarakat. ( Nurudin, 2000:97).

Opinion leader juga dapat diartikan sebagai orang yang sering dimintai petunjuk dan informasi oleh kebanyakan masyarakat, meneruskan informasi politik dari media massa kepada masyarakat. Misalnya tokoh informal masyarakat kharismatis, atau siapapun yang dipercaya oleh publik.

Nurudin mengemukakan beberapa ciri opinion leader beserta proses komunikasi yang dijalankannya sebaga berikut: Nurudin, 2004:93)

Opinion leader bukanlah manusia yang serba tau akan segala hal, tetapi kelebihannya adalah bahwa mereka diangap orang yang lebih peka dan in

\section{Jurnal Sociopolitico}


group serta tahu adat kebiasaamn masyarakat. Mereka memiliki jiwa sosial yang tinggi serta selalu siap memantu perubahan sosial di lingkungannya.

\section{Metode Penelitian}

Penelitian tentang peran opinion leader terhadap sosialisasi pola hidup bersih dan sehat pada masyarakat di kabupaten Kotawaringin Timur ini menggunakan metode penelitian deskriptif kualitatif. Penelitian deskriptif kualitatif bertujuan untuk memberikan gambaran tentang suatu masyarakat atau suatu kelompok orang tertentu atau gambaran tentang suatu gejala atau hubungan antara dua gejala atau lebih (Irawan Soehartono,2000: 35).

Metode yang digunakan adalah studi kasus yang menguraikan dan menjelaskan mengenai berbagai aspek secara individu, suatu kelompok, suatu organisasi, program, maupun situasi sosial.

Metode deskriptif adalah metode yang hanya memaparkan, menuliskan, dan melaporkan keadaan suatu objek ataupun suatu peristiwa yang berupa penyingkapan sebuah fakta. Sedangkan metode studi kasus adalah metode penelitian tentang subjek penelitian berupa individu, kelompok, lembaga, atau masyarakat, yang berkenaan dengan suatu fase atau tahap, sehingga dapat memberikan gambaran secara mendetail tentang latar belakang, sifat dan karakter yang khas dari suatu kasus. (Tim Sosiologi, 2000: 95104).

\section{Hasil dan Pembahasan}

\section{Jurnal Sociopolitico}

Fakultas Ilmu Sosial dan Ilmu Politik

\section{Membangun Citra Kerja Antara Pimpinan Kepala Desa Terhadap Masyarakat Di Desa Bukit Harapan Kecamatan Parenggean Kabupaten Kotawaringin Timur}

Keadaan masyarakat di Desa Bukit Harapan Kecamatan Parenggean Kabupaten Kotawaringin Timur mengenai peran kepala desa sebagai pemimpin desa adalah ditemukan semacam simbiosis yang erat antara masyarakat.

Peranan kepala desa di Desa Bukit Harapan Kecamatan Parenggean Kabupaten Kotawaringin Timur tidak hanya pada aspek politik, maupun keagamaan, melainkan bisa lebih luas, sehingga kepala desa menjadi figur panutan masyarakat Desa Bukit Harapan Kecamatan Parenggean Kabupaten Kotawaringin Timur, hal ini terlihat dari hasil wawancara dengan beberepa masyarakat di Desa Bukit Harapan Kecamatan Parenggean Kabupaten Kotawaringin Timur.

Tanggapan masyarakat tentang peran kepala desa sebagi di Desa Bukit Harapan Kecamatan Parenggean Kabupaten Kotawaringin Timur, disini peneliti memfokukskan pada pemimpin seorang kepala desa dalam pandangan masyarakat Desa Bukit Harapan Kecamatan Parenggean Kabupaten Kotawaringin Timur.

Beberapa pendapat ketika peneliti menanyakan kepada Warga Desa Bukit Harapan Kecamatan Parenggean Kabupaten Kotawaringin Timur mengenai peran Kepala Desa yang menjadi Opinion Leader atau panutan di Desa Bukit Harapan Kecamatan Parenggean Kabupaten Kotawaringin Timur ini, di antaranya yaitu kedalaman ilmu dan luas pengetahuan, serta perilaku yang sesuai tuntunan agama, dan juga ke-kharismatik- 
an sang kepala desa. Diantara sekian krtiteria itulah yang menjadi faktor dominan, sehingga pada masyarakat Desa Bukit Harapan Kecamatan Parenggean Kabupaten Kotawaringin Timur sangat tidak tunduk dan respek terhadap keberadaan kepala desa di Desa Bukit Harapan Kecamatan Parenggean Kabupaten Kotawaringin Timur. Peranan kepala desa dalam kehidupan sosial keagamaan masih sangat perlu dirubah, tentu banyak penelitian sebelumnya yang mengungkapkan hal ini.

Peran kepala desa sebagai panutan masyarakat. Salah satu hasil pengamatan dari kepala desa ikut serta membantu warga Desa Bukit Harapan Kecamatan Parenggean Kabupaten Kotawaringin Timur untuk ikut membantu keluarga itu. Karena menurut pengamatan peneliti sebelumnya hampir sebagian ada yang perduli dengan orang yang mau membuat pondasi rumah, dikarenakan orang tersebut tergolong masyarakat miskin, sehingga ketika kepala desa menyerukan kepada Desa Bukit Harapan Kecamatan Parenggean Kabupaten Kotawaringin Timur untuk menolong orang itu warga pun langsung ikut serta dalam pembangunan pondasi (di Desa Bukit Harapan Kecamatan Parenggean Kabupaten Kotawaringin Timur tidak ada semacam diskriminasi antara orang miskin dan kaya, walaupun tidak terlihat secara terang-terangan).

Menurut warganya salah satu tokoh desa berpendapat tentang peranan kepala desa yaitu kepala desa masih sangat kurang berkomunikasi kepada warganya dan masih perlu di perbaiki sang tokoh memberikan semacam wejangan dari seorang pemimpin, entah itu merupakan pemimpin desa maupun pemimpin negara, dan dari penuturannya saat itu diwawancarai oleh peneliti bahwa seorang pemimpin desa wajib memberikan contoh yang baik terhadap warganya, walaupun tidak menyebutkan nama atau keterangan, akan tetapi hampir semua warganya mengetahui apa yang dimaksud dan siapa figur yang akan dipilih untuk pemilihan selanjutnya untuk menjadi pemimpin Desa Bukit Harapan Kecamatan Parenggean Kabupaten Kotawaringin Timur.

\section{Peran Kepala Desa Sebagai Opinion Leader}

Negara berkewajiban melayani setiap warga negara dan penduduk untuk memenuhi hak dan kebutuhan dasarnya dalam kerangka pelayanan publik yang merupakan amanat Undang-Undang Dasar Negara Republik Indonesia Tahun 1945.

Kewajiban

pemerintah membangun kepercayaan masyarakat atas pelayanan publik yang dilakukan penyelenggara pelayanan publik merupakan kegiatan yang harus dilakukan seiring dengan harapan dan tuntutan seluruh warga negara dan penduduk tentang peningkatan pelayanan publik.

Pelayanan publik adalah kegiatan atau rangkaian kegiatan dalam rangka pemenuhan kebutuhan pelayanan sesuai dengan peraturan perundang- undangan bagi setiap warga negara dan penduduk atas barang, jasa, dan / atau pelayanan administratif yang disediakan oleh penyelenggara pelayanan publik. Penyelenggara pelayanan publik adalah setiap institusi penyelenggara negara, korporasi, lembaga independen yang dibentuk berdasarkan undang- undang untuk kegiatan pelayanan publik, dan badan hukum lain yang dibentuk sematamata untuk kegiatan pelayanan publik. Hilangnya kepercayaan masyarakat 
terhadap penyelenggara pelayanan publik akan berakibat rusaknya tatanan hukum dan aturan yang menjadi prasyarat bagi suatu kedaulatan negara. Peraturan dan keteraturan (rule and order) menjadi modal dasar bagi terbangunnya demokrasi dan keadilan dalam masyarakat.

Menurut kepala desa Bukit Harapan dalam komunikasi sangat kurang terhadap masyarakat dan kepala desa melaksanakan program kerja yang terlaksana yaitu:

"Program-Program Kerja Yang Terlaksana Dalam Pemrintahan"

1. Sifat Kepemimpinan : yang langsung dibuat di desa dan melibatkan masyarakat langsung, seperti gotongroyong.

2. Program Uang Negara: kita disini dalam teknis pendidikan, dan kesehatan, dalam intra strutuktur. Gambaran adanya dana sumbernya ditahun 2017 kita melakukan pembanguna jalan, pembuatan got, gedung TK, Paud, Posyandu, dan perbaikan sarana dan prasarana dikantor-kantor melalui anggaran APBD. Pengelolaan ini tidak lepas dari musawarah masyarakat dalam musawarah bersama desa.

3. Tujuan kami dalam Visi atau Misi desa peran kita untuk membaangun kesejahteraan masayarakat desa, sangat membangun pemerintah melibatkan organisasi-organisasi, usaha-usaha kecil, dan usaha-usaha menengah untuk bisa membantu masyarakat, dan dananya untuk usaha tersebut untuk memajukan sarana dan prasarana desa.

Selanjutnya Masyarakat Memberikan Pernyataan Sebagai Berikut:
"Kepala desa di Bukit Harapan ini komunikasi cukup baik dalam menyapa masyarakatnya, terjadinya kesalah pahaman dalam komunikasi kerena diakibatkan pada saat penyampaian kepada warga kurang jelas kepada aparat atau staf desa yang ditugaskan untuk menyampaikannya.

Tati : Komunikasi kepala desa kita cukup baik, baik dalam pelayanan kepada warganya, sudah terlayani walaupun ada dari sebagian warga ada yang kurang puas terhadap pelayanan kepala desa.

Karin : Dalam hal komunikasi cukup bagus karena kepala desa adalah orang asli daerah tersebut dan dapat membaur dengan warganya.

Rio : walaupun kepala desa jarang turun kekantor desa, tetapi apabila ada masalah maka warga dapat langsung dating kerumah kepala desa untuk berurusan sesuai dengan kepentingan masingmasing.

\section{Kesimpulan}

1. Dalam peraturan desa Kepala Desa di Desa Bukit Harapan Kecamatan Parenggean Kabupaten Kotawaringin Timur telah menyelesaikan proker desa yang dibuat dan semua anggota ikut serta dalam menjalankan proker kerja, dan visi/misi yang ada didesa sangat berjalan dengan baik, serta sekertaris desa sangat membantu dalam peraturan desa yang dijalankan dalam pemerintahan.

2. Hambatan yang dialami di kantor pemerintahan desa masih sangat kurangnya keterlibatan masyarakat terhadap program yang telah disusun oleh pemerintah desa, untuk selanjutnya agar partisifasi warga bisa ditingkatkan lagi agar proses 
pembangunan desa dapat berjalan dengan lancar adanya komunikasi yang baik antara pemerintah desa dan warganya.

\section{Referensi}

Ardianto, Elvinaro, 2004. Komunikasi Massa : Suatu Pengantar. Bandung: Simbiosa Rekatama Media.

Ardianto, Elvinaro dan Lukiati Komala Erdinaya. 2004. Komunikasi Massa Suatu. Pengantar. PT Remaja Rosdakarya : Bandung

Cangara, Hafied, 2008. Pengantar Ilmu Komunikasi. PT. Raja Grafindo Persada, Jakarta.

Everett M. Rogers. 2009 Cara mengetahui opinion leader. Bandung : Remaja Rosdakarya.

Elihu Katz, 2003 model arus komunikasi massa. Jakarta: 12 januari. Universitas press.

Gabriel Tarde .2002 Karateristik Opinion Leader. Surakarta: Sebelas Maret University Press.

Jahi, Amri. 1993. Komunikasi Massa dan Pembangunan Pedesaan di NegaraNegara Dunia Ketiga: Suatu Pengantar. Jakarta: PT Gramedia Pustaka Utama.

Kartini, Kartono, 1994. Pemimpin dan Kepemimpinan, Jakarta : PT. Raja Grafindo Perkasa.

Lazarsfeld Paul,. 2009 Peranan Opinion Leader Dalam Meningkatkan Peran Politik Masyarakat Perdesaan dalam Pembangunan. Jakarta.

Maryanto, Ibnu., dkk. 2007. Nama Daerah Mamalia di Indonesia. Jakarta: LIPI Press.
Moch. Solekhan, 2012, "Penyelenggaraan Pemerintahan Desa", Setara, Malang.

Moleong, Lexy J, 1995 Metode Penelitian Kualitatif, Bandung: Remaja Rosda Karya.

Moleong, Lexy J., 1999 Metodologi Penelitian Kualitatif, Bandung: Remaja Rosdakarya.

Nasution, Zulkarimein. 1996. Komunikasi Pembangunan: Pengenalan Teori dan Penerapannya. Jakarta: PT Raja Grafindo Persada.

Nurudin, . Opinion leader . Jakarta : Rajawali Pers. 2000:97

Nurudin. 2007. Pengantar Komunikasi Massa. Jakarta : PT. Rajagrafindo Persada.

Nurudin. 2004. Pengaruh Kelompok Refrensi (Opinion Leader Dan Keluarga) Terhadapperilaku Konsumen. Bandung.

Nurudin. Pengantar Komunikasi Massa. Jakarta : PT. Rajagrafindo Persada. 2007

Nurudin. 2004. Komunikasi Massa. Malang : CESPUR.

Nurdin.2004. Sistem Komunikasi Indonesia. Jakarta : Devisi Buku Perguruan Tinggi. Raja Grafindo Persada.

Rakhmat, Jalaluddin. 2004. Metode Penelitian Komunikasi. Bandung : Remaja Rosdakarya.

Riyono Pratikto, 2007. Cara mengetahi opinion leader. Yoyakkarta : gadjah mada university press.

Rogers dengan Svenning. 2004. Karateristik Opinion Leader. Surakarta: Sebelas Maret University Press.

Sendjaja, Sasa, Djuarsa, 1993. Pengantar Ilmu Komunikasi. Universitas Terbuka, Jakarta.

\section{Jurnal Sociopolitico}


Soehartono, irawan, 2001. Penelitian deskriftif kualitatif. Surabaya. Media cetak.

Shadily .Hasan, 1993 Sosiologi untuk masyarakat Indonesia (Jakarta :PT. Rineka Cipta.

Sugiyono, Dr. 2010. Metode penelitian Kuantitatif Kualitatif dan R\&D, Penerbit ALFABETA.

Sugiono, 2000, Metode penelitian kualitatif. Rajawali. Jakarta.

, 2001, Metode penelitian kualitatif. Rajawali . Jakarta.

, 2009, Metode penelitian kualitatif. Rajawali . Jakarta.

Van De Ban.2002. opinion leader dalam komunikasi. Jakarta. Bandung. Grafindo persada. 